Journal of Animal and Veterinary Advances 11 (19): 3499-3505, 2012

ISSN: $1680-5593$

(C) Medwell Journals, 2012

\title{
Polymorphisms in Exon 2 of $I G F-I R$ Gene and Theirs Association with Production Traits in Jinghai Yellow Chicken
}

\author{
${ }^{1}$ Fengping Yang, ${ }^{2}$ Chongfu Jin, ${ }^{2}$ Guojun Dai, ${ }^{2}$ Kaizhou Xie, ${ }^{3}$ Yabo Yu and ${ }^{2}$ Jinyu Wang \\ ${ }^{1}$ College of Bioscience and Technology, ${ }^{2}$ College of Animal Science and Techology, \\ Yangzhou University, 225009 Yangzhou, China \\ ${ }^{3}$ Jiangsu Jinghai Poultry Group Co., Ltd. 226103 Haimen, China
}

\begin{abstract}
In this study, exon 2 of Insulin-like Growth Factor Receptor type I (IGF-IR) gene was studied as a candidate gene associated with production performance in Jinghai Yellow chicken. A pair of primers was designed to screen the Single Nucleotide Polymorphisms (SNPs) using DNA pooling which consisted of DNA from all 200 female chickens and three pairs of primers were then designed to check them individually. The result showed there were three SNPs (G26333A, G26336A and C26639T) in the chicken group, each had three genotypes and was in Hardy-Weinberg equilibrium $(\mathrm{p}>0.05)$. Correlation analysis showed the $\mathrm{G}$ to $\mathrm{A}$ transition at 26333 bp was negatively associated with 300 days egg number and body weight at 4 and 16 weeks of age, the $\mathrm{G}$ to A transition at $26336 \mathrm{bp}$ was positively associated with body weight at 8 and 12 weeks of age and the $\mathrm{C}$ to $\mathrm{T}$ transition at $26639 \mathrm{bp}$ was positively associated with body weight at 16 weeks of age. Com-genotype analysis showed that the age at the first egg of chickens with $\mathrm{AA} / \mathrm{CD} / \mathrm{EE}$ was earlier than those with $\mathrm{AA} / \mathrm{CC} / \mathrm{EE}$ and $\mathrm{AB} / \mathrm{CC} / \mathrm{EF}(\mathrm{p}<0.05)$ and chickens with $\mathrm{AB} / \mathrm{CC} / \mathrm{EE}$ had more 300 days egg number than those with $\mathrm{BB} / \mathrm{CD} / \mathrm{EE}(\mathrm{p}<0.05)$. $\mathrm{AA} / \mathrm{CC} / \mathrm{EF}$ was an enhancing com-genotype for body weight while $\mathrm{AA} / \mathrm{CC} / \mathrm{EE}$ and $\mathrm{AB} / \mathrm{CC} / \mathrm{EF}$ were the negative ones at 12 and 16 weeks of age. The results suggested a significant association between SNPs of $I G F-I R$ gene and production traits and these SNPs could be used as potential genetic markers in future breeding of Jinghai yellow chicken.
\end{abstract}

Key words: Jinghai Yellow chicken, exon 2 of $I G F-I R$ gene, polymorphism, productive traits, China

\section{INTRODUCTION}

The Insulin-like Growth Factor system (IGFs) is composed of Ligands (IGF-I, IGF-II), Receptors (IGF-IR, IGF-IIR) and a family of binding Proteins (IGFBPs) (Donovan and Kummar, 2008) with a strong promotion of growth and differentiation. IGF-IR is the main mediator of IGFs among two receptors, expresses after the eight-cell stage (Rappolee et al., 1992) and ubiquitously distributes in normal tissues and cells in human body (Coppola et al., 1994). It has important functions in immunoloregulation, mitogenic responses, growth of muscle and skeleton (Denley et al., 2005) working with Platelet Derived Growth Factor (PDGF), Epidermal Growth Factor (EFG) and Fibroblast Growth Factor (FGF) (Leroith et al., 1995; Meyts et al., 1994; Baserga et al., 1994). Expression of $I G F-I R$ gene increases 4-5 fold in Atlantic salmon in May and June, coincided with an increase in bone density (Wargelius et al., 2005). IGF-IR-null mutation in mature osteoblasts leads to less bone, decreases periosteal bone formation, impairs stimulatory effects of parathyroid hormone on osteoprogenitor cell proliferation and differentiation in mice (Wang et al., 2007). IGF-IR staining of immature mouse declines considerably with age in the proximal femur and distal tibia (hip and ankle) but expression remains high in distal femur and proximal tibia (knee) throughout growth (Serrat et al., 2007). IGF-IR is also closely related with the occurrence, development and metastasis of cancer (Burfeind et al., 1996; Waksmanski et al., 2001; Zhao et al., 2004).

In chicken, IGF-IR gene locates on chromosome 10, consists of 21 exons and codes for 1363 amino acid residues. Mature IGF-IR is composed of two $\alpha$ and two $\beta$ chains held together by disulfide bonds (Bhaumick et al., 1981; Chernausek et al., 1981; Massague and Czech, 1982), its 1333 amino acid residues was found $85 \%$ homology with that of human (Matsumura et al., 1996). At present, researchers do their best to find certain correlation between gene and production performance of livestock to offer some useful ways for molecular-assistant breeding. Lei et al. (2006) considered the mutation in exon 3 of $I G F-I R$ gene was significantly correlated with growth and slaughter traits in chicken; Gao et al. (2009) draw conclusions that C919G mutation in

Corresponding Author: Jinyu Wang, College of Animal Science and Techology, Yangzhou University, 225009 Yangzhou, China 
exon 4 of $I G F-I R$ gene significantly affected 5 weeks body weight $(\mathrm{p}<0.05)$ and $\mathrm{T} 2761 \mathrm{C}$ in exon 13 significantly affected metatarsus circle, metatarsus and ungual ratio $(\mathrm{p}<0.01)$ and was also correlated with metatarsus, ungual weight and femur weight $(\mathrm{p}<0.05)$. A significant effect of a SNP genotype was found on 10 weeks body weight $(\mathrm{p}<0.01)$, 4-10 and 6-10 weeks average daily gain $(\mathrm{p}<0.05)$ in Japanese quail (Moe et al., 2007).

Jinghai yellow chicken is the first chicken breed after the enactment of the new Animal Husbandry Law of the People's Republic of China in 2006. It is a high quality, small meat chicken breed and is widely accepted in Jiangsu Province. In the present study, researchers analyzed the polymorphisms of exon 2 of $I G F-I R$ gene in female Jinghai yellow chicken, explored the association between its SNPs and production performances aiming to enrich the characteristic of IGF-IR gene in Jinghai Yellow chicken and to find more useful molecular breeding methods for this new breed.

\section{MATERIALS AND METHODS}

Chicken populations: A total of 200 female Jinghai Yellow chickens belonging to generation eight, bred in Jiangsu Jinghai Poultry Group Co., Ltd. were sampled. Growth traits (including hatch weight and body weight at 4, 8, 12, 16 weeks of age) and reproductive traits (including age at first egg, beginning-laying-weight, primary egg weight and 300 days egg number) of each individual were noted. Blood samples were obtained from the wing vein with sodium heparin as an anticoagulant and then stored at $-20^{\circ} \mathrm{C}$. Genomic DNA was extracted from the whole blood using the phenol-chloroform method. DNA concentrations were quantified spectrophotometrically.

Primers design and PCR amplification: Based on DNA sequence of IGF-IR (GenBank Accession No. NC_006097), a pair of Primers $(\mathrm{P})$ was designed with Primer Premier 5.0 Software. Using pool DNA as template, the PCR amplification was to screen out SNPs in exon 2 of $I G F-I R$ gene. The DNA pooling was constructed by fully mixed 200 DNA samples, each was $5 \mu \mathrm{L}$. According to the sequencing result, three pairs of primers, P2 for RFLP and the other two for SSCP were designed to detect the SNPs in each chicken (Table 1).
PCR was performed in a total volume of $20 \mu \mathrm{L}$ which included $2.0 \mu \mathrm{L} 10 \times$ buffer, $2.2 \mu \mathrm{L} \mathrm{Mg}^{2+}\left(20 \mathrm{mmol} \mathrm{L}^{-1}\right)$, $0.8 \mu \mathrm{L}$ dNTPs $\left(2.5 \mathrm{mmol} \mathrm{L^{-1 }}\right), 1.0 \mathrm{~L}$ each primer $\left(10 \mu \mathrm{mol} \mathrm{L}^{-1}\right), 1.0 \mu \mathrm{L}$ template DNA $\left(100 \mathrm{mg} \mathrm{L}^{-1}\right), 0.2 \mu \mathrm{L}$ Taq DNA polymerase $(2 \mathrm{U} \mu \mathrm{L})$ and $11.8 \mu \mathrm{L} \mathrm{ddH}_{2} \mathrm{O}$. Amplification conditions were all as follows: denaturation at $95^{\circ} \mathrm{C}$ for $6 \mathrm{~min}$ followed by 30 cycles of $95^{\circ} \mathrm{C}$ for $30 \mathrm{sec}$, $58-62^{\circ} \mathrm{C}$ for $30 \mathrm{sec}, 72^{\circ} \mathrm{C}$ for $30 \mathrm{ec}$ and a final extension at $72^{\circ} \mathrm{C}$ for $10 \mathrm{~min}$. PCR products were verified by electrophoresis on $1 \%$ agarose gel in $0.5 \times \mathrm{TBE}$ and stained with gold view.

For SSCP analysis, $2.5 \mu \mathrm{L}$ of amplified product was mixed with $7.5 \mu \mathrm{L}$ denaturing buffer (95\% formamide, $0.5 \%$ bromophenol blue, $0.5 \%$ xylene cyanole $\mathrm{FF}$ and $10 \mathrm{mmol} \mathrm{L}^{-1}$ EDTA ( $\mathrm{pH} \mathrm{8.0)}$ ), heated for $6 \mathrm{~min}$ at $95^{\circ} \mathrm{C}$ then immediately chilled on ice for $5 \mathrm{~min}$. Electrophoresis was performed on $10 \%$ non-denaturing polyacrylamide gel at $250 \mathrm{~V}$ for $10-15 \mathrm{~h}$ at $16^{\circ} \mathrm{C}$, SSCP patterns on the gels were visualized by silver staining ( $\mathrm{Xu}$ et al., 2002).

For RFLP, restriction digests were performed in a $20 \mu \mathrm{L}$ reaction including $10 \mu \mathrm{L}$ amplified product, $2.0 \mu \mathrm{L}$ $10 \times$ buffer, $7.6 \mu \mathrm{L}$ dd $\mathrm{H}_{2} \mathrm{O}$ and $0.4 \mu \mathrm{L}$ Alu I. Reactions were incubated in $37^{\circ} \mathrm{C}$ through a night and digested products were separated on $10 \%$ polyacrylamide gel. DNA bands were stained with silver. PCR products of homozygous/heterozygous individuals of different genotypes were purified with a DNA Fragment Quick Purification/Recover kit. The purified PCR products were sequenced in both directions, completed by Shanghai Invitrogen Biotechnology Co.

Statistical analysis: Hardy-Weinberg equilibrium was tested for each SNP using the $\chi^{2}$-test. The General Linear Model (GLM) was established to analyze the genotype effects of exon 2 in $I G F-I R$ gene on body weight and reproductive traits. The model was used as:

$$
\mathrm{y}_{\mathrm{ij}}=\mu+\mathrm{G}_{\mathrm{i}}+\mathrm{e}
$$

Where:

$$
\begin{aligned}
\mathrm{y}_{\mathrm{ij}} & =\text { Value of production traits } \\
\mu & =\text { Mean value } \\
\mathrm{G}_{\mathrm{i}} & =\text { The fixed effect of each SNP } \\
\mathrm{e} & =\text { The residual error }
\end{aligned}
$$

\begin{tabular}{|c|c|c|c|c|}
\hline Primers & Primer sequence $\left(5^{\prime}-3^{\prime}\right)$ & Position in NC 006097 & Annealing Temp. $\left({ }^{\circ} \mathrm{C}\right)$ & Length (bp) \\
\hline$\overline{\mathrm{P}}$ & F:CCATGGGAATAGCCTACGTG & $26114-26774$ & 60 & 661 \\
\hline & R:ACAGAGAGCACAGCTCCTCA & & & \\
\hline P1 & $\begin{array}{l}\text { F:AACGCCTGGAGAACTGTACG } \\
\text { R:AGTCAGTTATGACGGTCAGCTT }\end{array}$ & $26246-26355$ & 58 & 111 \\
\hline $\mathrm{P} 2$ & $\begin{array}{l}\text { F: AACGCCTGGAGAACTGTACG } \\
\text { R:ATCGCTGAGGCTTTCCAAG }\end{array}$ & 26246-26402 & 62 & 155 \\
\hline P3 & $\begin{array}{l}\text { F:GGCCATACGGATTGAGAAGA } \\
\text { R:ATGGAGGTCTTCTCGCACAA }\end{array}$ & $26523-26696$ & 58 & 174 \\
\hline
\end{tabular}

Table 1: Primers designed to amplify exon 2 of $I G F-I R$ gene in Jinghai yellow chickens 
Differences among genotypes or com-genotypes were analyzed using SPSS 16.0 Software. For all companions, differences were considered to be statistically significant if $\mathrm{p}<0.05$.

\section{RESULTS}

Sequencing result of the amplification product of DNA pooling: Checking the sequence of amplification product of DNA pooling, double peaks were found in three positions (26333, 26336 and 26639 bp) (Fig. 1) which signified that there would be three SNPs possibly. And further analysis showed there would be a change of Alu I endonuclease locus at $26336 \mathrm{bp}$.

PCR amplification, SSCP and RFLP analysis: The PCR products amplified by three pairs of primers were ideal and each all displayed polymorphisms. For primer P1, three genotypes were detected and were named $\mathrm{AA}, \mathrm{AB}$ and $\mathrm{BB}$, respectively (Fig. 2) for primer $\mathrm{P} 3$, three genotypes, $\mathrm{EE}, \mathrm{EF}$ and $\mathrm{FF}$ were observed also (Fig. 3). For primer P2, the amplified 155 bp fragment, digested with Alu I, yielded products of 90 and $65 \mathrm{bp}$ for the C allele and $155 \mathrm{bp}$ for the $\mathrm{D}$ allele and three genotypes (CC, CD and DD) were detected (Fig. 4).

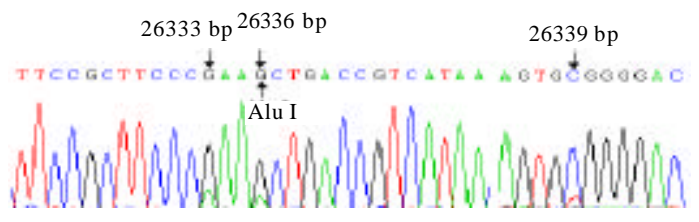

Fig. 1: Sequence alignment of amplification of DNA pooling

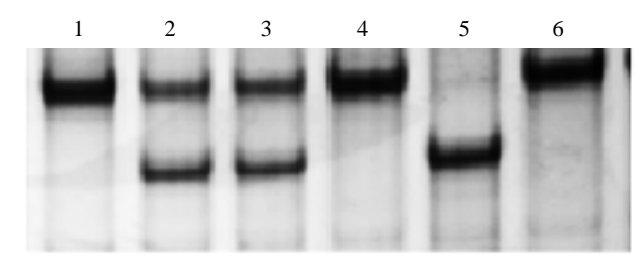

Fig. 2: SSCP analysis of PCR amplification using primer P1 Lanes 1, 4 and 6: AA genotype; Lanes 2, 3: AB genotype; Lane 5: BB genotype

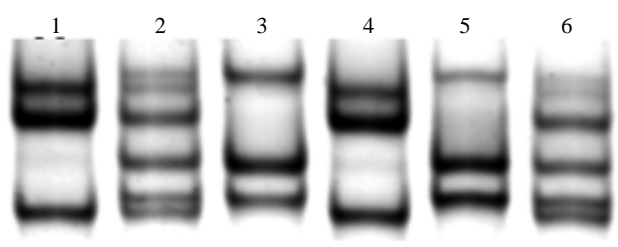

Fig. 3: SSCP analysis of PCR amplification using primer P3 Lanes 1 and 4: FF genotype; Lanes 2, 6: EF genotype; Lane 3, 5: EE genotype
Sequence analysis: $\mathrm{PCR}$ products of $\mathrm{AA}$ and $\mathrm{BB}$ were cloned and sequenced and a synonymous mutation, $G$ to A was found at the position of $26333 \mathrm{bp}$ between them (Fig. 5). In the similarly way, $\mathrm{G}$ to $\mathrm{A}$ at $26336 \mathrm{bp}$ between CC and DD (Fig. 6) and C to T at 26639 bp between EE and $\mathrm{FF}$ (Fig. 7) were revealed and the two were also synonymous base mutation.

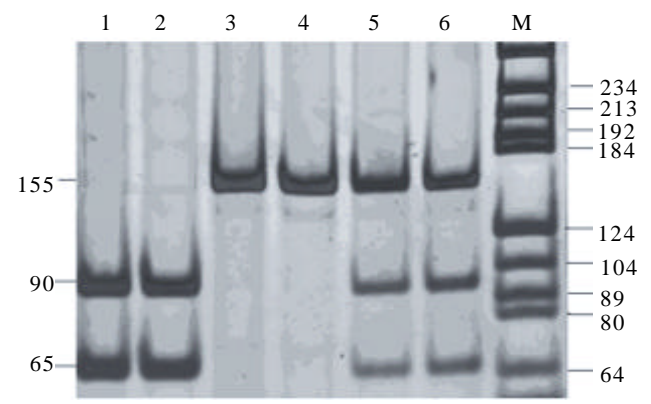

Fig. 4: RFLP analysis of PCR amplification using primer P2 Lanes 1 and 1, 2: CC genotype; Lanes 3, 4: DD genotype; Lane 5, 6: CD genotype; M: DNA marker pBR322
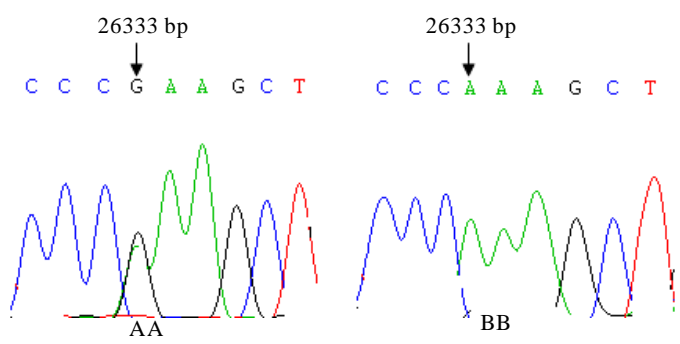

Fig. 5: Sequence alignment of $\mathrm{AA}$ and $\mathrm{AB}$ of primer $\mathrm{P} 1$

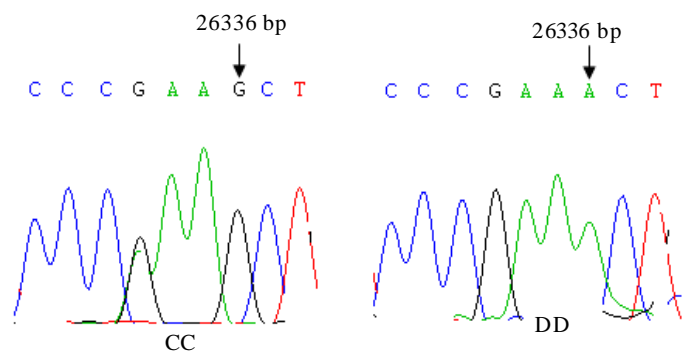

Fig. 6: Sequence alignment of $\mathrm{CC}$ and $\mathrm{DD}$ of primer $\mathrm{P} 2$

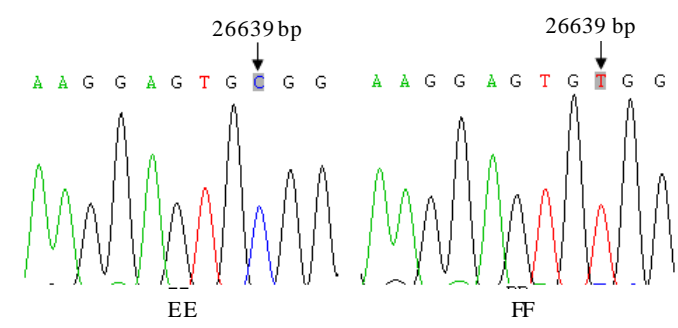

Fig. 7: Sequence alignment of $\mathrm{EE}$ and $\mathrm{FF}$ of primer $\mathrm{P} 3$ 
Genotype and allele frequencies in Jinghai Yellow chicken group: Frequencies of genotypes and alleles are shown in Table 2. In three SNP loci, A, C and E were the dominant alleles in this chicken group with frequencies of $0.855,0.755$ and 0.870 , respectively and $\mathrm{AA}, \mathrm{CC}$ and $\mathrm{EE}$ were the dominant genotypes with frequencies of 0.745 , 0.555 and 0.765 . The $\chi^{2}$-test showed that the observed genotypic values of three SNPs were not statistically different from the expected values, based on the Hardy-Weinberg equilibrium.

Table 2: Genotype and allele frequency of three SNPs in Jinghai Yellow chicken

\begin{tabular}{|c|c|c|c|c|c|c|}
\hline \multirow{2}{*}{$\begin{array}{l}\text { Primers } \\
\text { P1 }\end{array}$} & \multicolumn{3}{|c|}{-------Genotype frequency--------- } & \multicolumn{2}{|c|}{--Allele frequency-- } & \multirow{2}{*}{$\frac{\chi^{2}}{2.541}$} \\
\hline & $\mathrm{AA}: 0.745$ & AB: 0.220 & $\mathrm{BB}: 0.035$ & $\mathrm{~A}: 0.855$ & B:0.145 & \\
\hline $\mathrm{P} 2$ & $\mathrm{CC}: 0.555$ & $\mathrm{CD}: 0.400$ & DD:0.045 & $\mathrm{C}: 0.755$ & $\mathrm{D}: 0.245$ & 0.988 \\
\hline$\underline{\mathrm{P} 3}$ & $\mathrm{EE}: 0.765$ & $\mathrm{EF}: 0.210$ & $\mathrm{FF}: 0.025$ & $\mathrm{E}: 0.870$ & $\mathrm{~F}: 0.130$ & 1.026 \\
\hline
\end{tabular}

Association of genotypes with production performances: Chickens with $\mathrm{AA}$ and $\mathrm{AB}$ genotypes had significantly higher 300 days egg number and body weight at 4 weeks than those with $\mathrm{BB}$ genotypes $(\mathrm{p}<0.05)$ (Table 3 ). Chickens with AA had higher body weight at 16 weeks than those with $\mathrm{BB}(\mathrm{p}<0.05)$. Chickens with $\mathrm{DD}$ had higher body weight at 8 weeks than those with $C C(p<0.05)$ and they also had higher body weight at 12 weeks than those with $C C$ and $C D(p<0.05)$. For primer $P 3$, chickens with EE and $E F$ had higher body weight at 16 weeks than those with FF $(\mathrm{p}<0.05)$.

Association between com-genotypes and production performances: The least square means and SE for body weight and reproductive traits of different com-genotypes in Jinghai yellow chicken are shown in Table 4. For

Table 3: Association of genotypes with production performances in Jinghai Yellow chicken (Mean $\pm \mathrm{SE}$ )

\begin{tabular}{|c|c|c|c|c|}
\hline \multirow[b]{2}{*}{ Primers } & \multirow[b]{2}{*}{ Traits } & \multicolumn{3}{|l|}{ Genotypes } \\
\hline & & $\mathrm{AA}(\mathrm{N}=149)$ & $\mathrm{AB}(\mathrm{N}=44)$ & $\mathrm{BB}(\mathrm{N}=7)$ \\
\hline \multirow[t]{10}{*}{$\mathrm{P} 1$} & Age at first egg & $140.51 \pm 0.85$ & $140.64 \pm 1.56$ & $143.14 \pm 3.91$ \\
\hline & Beginning lay ing weight & $1569.67 \pm 15.48$ & $1572.68 \pm 28.49$ & $1510.86 \pm 71.44$ \\
\hline & Primary egg weight & $33.05 \pm 0.40$ & $32.68 \pm 0.74$ & $32.71 \pm 1.87$ \\
\hline & 300 days egg number & $95.54 \pm 1.73^{\mathrm{a}}$ & $96.36 \pm 3.18^{\mathrm{a}}$ & $77.00 \pm 7.96^{6}$ \\
\hline & Hatch weight & $35.30 \pm 0.36$ & $35.75 \pm 0.66$ & $37.14 \pm 1.65$ \\
\hline & Body weight at 4 weeks & $193.27 \pm 2.10^{\mathrm{a}}$ & $186.93 \pm 3.86^{\mathrm{a}}$ & $168.57 \pm 9.67^{b}$ \\
\hline & Body weight at 8 weeks & $481.83 \pm 6.09$ & $471.14 \pm 11.21$ & $449.29 \pm 28.10$ \\
\hline & Body weight at 12 weeks & $894.28 \pm 10.06$ & $884.71 \pm 18.51$ & $820.43 \pm 46.40$ \\
\hline & Body weight at 16 weeks & $1146.26 \pm 8.36^{\mathrm{a}}$ & $1136.82 \pm 15.38^{\mathrm{ab}}$ & $1064.14 \pm 38.55^{b}$ \\
\hline & & $\mathrm{CC}(\mathrm{N}=111)$ & $\mathrm{CD}(\mathrm{N}=80)$ & $\mathrm{DD}(\mathrm{N}=9)$ \\
\hline \multirow[t]{10}{*}{ P2 } & Age at first egg & $142.03 \pm 0.97$ & $138.38 \pm 1.14$ & $143.44 \pm 3.39$ \\
\hline & Beginning lay ing weight & $1572.58 \pm 17.88$ & $1553.70 \pm 21.06$ & $1644.78 \pm 62.79$ \\
\hline & Primary egg weight & $32.98 \pm 0.47$ & $32.88 \pm 0.55$ & $33.33 \pm 1.65$ \\
\hline & 300 days egg number & $94.41 \pm 2.03$ & $95.95 \pm 2.39$ & $95.44 \pm 7.12$ \\
\hline & Hatch weight & $35.76 \pm 0.41$ & $35.08 \pm 0.49$ & $35.22 \pm 1.45$ \\
\hline & Body weight at 4 weeks & $189.88 \pm 2.47$ & $191.96 \pm 2.91$ & $196.44 \pm 8.68$ \\
\hline & Body weight at 8 weeks & $472.28 \pm 7.02^{b}$ & $482.08 \pm 8.27^{\mathrm{ab}}$ & $519.89 \pm 24.66^{\mathrm{a}}$ \\
\hline & Body weight at 12 weeks & $884.78 \pm 11.54^{b}$ & $884.85 \pm 13.59^{b}$ & $991.00 \pm 40.52^{\mathrm{a}}$ \\
\hline & Body weight at 16 weeks & $1132.05 \pm 9.73$ & $1154.96 \pm 11.46$ & $1134.22 \pm 34.17$ \\
\hline & & $\mathrm{EE}(\mathrm{N}=153)$ & $\mathrm{EF}(\mathrm{N}=42)$ & $\mathrm{FF}(\mathrm{N}=5)$ \\
\hline \multirow[t]{9}{*}{ P3 } & Age at first egg & $140.68 \pm 0.84$ & $140.43 \pm 1.60$ & $140.80 \pm 4.63$ \\
\hline & Beginning lay ing weight & $1572.14 \pm 15.27$ & $1563.36 \pm 29.15$ & $1491.20 \pm 84.48$ \\
\hline & Primary egg weight & $33.28 \pm 0.40$ & $32.21 \pm 0.75$ & $29.40 \pm 2.18$ \\
\hline & 300 days egg number & $95.37 \pm 1.73$ & $94.55 \pm 3.29$ & $90.40 \pm 9.54$ \\
\hline & Hatch weight & $35.40 \pm 0.53$ & $35.79 \pm 0.67$ & $34.60 \pm 1.95$ \\
\hline & Body weight at 4 weeks & $191.80 \pm 2.10$ & $190.19 \pm 4.00$ & $173.80 \pm 11.59$ \\
\hline & Body weight at 8 weeks & $478.52 \pm 6.01$ & $482.38 \pm 11.48$ & $438.80 \pm 33.27$ \\
\hline & Body weight at 12 weeks & $890.26 \pm 9.99$ & $888.88 \pm 19.06$ & $875.20 \pm 55.24$ \\
\hline & Body weight at 16 weeks & $1142.16 \pm 8.24^{\mathrm{a}}$ & $1149.48 \pm 15.73^{\mathrm{a}}$ & $1046.80 \pm 45.60^{b}$ \\
\hline
\end{tabular}

Table 4: Association between com-genotypes and production performance in Jinghai Yellow chicken

\begin{tabular}{lcccccc} 
Com-genotype & $\begin{array}{c}\text { Age at } \\
\text { first egg }\end{array}$ & $\begin{array}{c}\text { Beginning } \\
\text { laying weight }\end{array}$ & $\begin{array}{c}\text { 300 days } \\
\text { egg number }\end{array}$ & $\begin{array}{c}\text { Body weight } \\
\text { at 8 weeks }\end{array}$ & $\begin{array}{c}\text { Body weight } \\
\text { at 12 weeks }\end{array}$ & $\begin{array}{c}\text { Body weight } \\
\text { at 16 weeks }\end{array}$ \\
\hline $\mathrm{AA} / \mathrm{CC} / \mathrm{EE}(72)$ & $142.74 \pm 9.930^{\mathrm{a}}$ & $1564.96 \pm 160.210^{\mathrm{abc}}$ & $93.68 \pm 21.01^{\mathrm{ab}}$ & $473.64 \pm 74.50$ & $885.12 \pm 117.64^{\mathrm{b}}$ & $1135.10 \pm 101.53^{\mathrm{b}}$ \\
$\mathrm{AA} / \mathrm{CC} / \mathrm{EF}(6)$ & $137.00 \pm 15.37^{\mathrm{ab}}$ & $1692.50 \pm 609.030^{\mathrm{a}}$ & $91.33 \pm 17.18^{\mathrm{ab}}$ & $507.50 \pm 34.17$ & $916.33 \pm 65.960^{\mathrm{ab}}$ & $1227.00 \pm 61.040^{\mathrm{a}}$ \\
$\mathrm{AA} / \mathrm{CD} / \mathrm{EE}(57)$ & $137.86 \pm 9.473^{\mathrm{b}}$ & $1562.04 \pm 169.870^{\mathrm{abc}}$ & $97.35 \pm 22.04^{\mathrm{ab}}$ & $484.33 \pm 75.36$ & $892.49 \pm 113.92^{\mathrm{b}}$ & $1154.88 \pm 104.11^{\mathrm{ab}}$ \\
$\mathrm{AA} / \mathrm{CD} / \mathrm{EF}(5)$ & $140.00 \pm 6.290^{\mathrm{ab}}$ & $1415.60 \pm 67.2500^{\mathrm{b}}$ & $102.20 \pm 9.010^{\mathrm{ab}}$ & $466.00 \pm 18.07$ & $810.60 \pm 86.960^{\mathrm{b}}$ & $1135.60 \pm 105.30^{\circ \mathrm{b}}$ \\
$\mathrm{AA} / \mathrm{DD} / \mathrm{EE}(9)$ & $143.44 \pm 6.860^{\mathrm{ab}}$ & $1644.78 \pm 217.940^{\mathrm{ac}}$ & $95.44 \pm 16.13^{\mathrm{ab}}$ & $519.89 \pm 65.17$ & $991.00 \pm 154.60^{\mathrm{a}}$ & $1134.22 \pm 120.28^{\mathrm{ab}}$ \\
$\mathrm{AB} / \mathrm{CC} / \mathrm{EE}(9)$ & $136.33 \pm 11.69^{\mathrm{ab}}$ & $1605.11 \pm 216.170^{\mathrm{abc}}$ & $103.89 \pm 17.60^{\mathrm{a}}$ & $450.55 \pm 83.31$ & $869.44 \pm 122.35^{\mathrm{b}}$ & $1131.33 \pm 105.90^{\mathrm{ab}}$ \\
$\mathrm{AB} / \mathrm{CC} / \mathrm{EF}(19)$ & $143.95 \pm 13.60^{\mathrm{a}}$ & $1569.58 \pm 131.120^{\mathrm{abc}}$ & $94.74 \pm 30.13^{\mathrm{ab}}$ & $475.11 \pm 88.42$ & $883.32 \pm 152.68^{\mathrm{b}}$ & $1113.26 \pm 103.12^{\mathrm{b}}$ \\
$\mathrm{AB} / \mathrm{CD} / \mathrm{EE}(3)$ & $146.33 \pm 12.42^{\mathrm{ab}}$ & $1571.67 \pm 149.670^{\mathrm{abc}}$ & $94.33 \pm 12.58^{\mathrm{ab}}$ & $446.67 \pm 55.30$ & $813.33 \pm 125.83^{\mathrm{b}}$ & $1156.67 \pm 33.310^{\mathrm{ab}}$ \\
$\mathrm{AB} / \mathrm{CD} / \mathrm{EF}(12)$ & $136.75 \pm 8.070^{\mathrm{ab}}$ & $1550.50 \pm 123.400^{\mathrm{abc}}$ & $92.67 \pm 13.50^{\mathrm{ab}}$ & $488.17 \pm 90.73$ & $916.58 \pm 145.95^{\mathrm{ab}}$ & $1173.83 \pm 85.650^{\mathrm{ab}}$ \\
$\mathrm{BB} / \mathrm{CC} / \mathrm{FF}(3)$ & $141.67 \pm 4.510^{\mathrm{ab}}$ & $1410.67 \pm 97.4500^{\mathrm{bc}}$ & $91.00 \pm 21.52^{\mathrm{ab}}$ & $443.00 \pm 55.25$ & $861.33 \pm 65.040^{\mathrm{ab}}$ & $1044.00 \pm 83.360^{\mathrm{b}}$ \\
$\mathrm{BB} / \mathrm{CD} / \mathrm{EE}(3)$ & $144.00 \pm 9.540^{\mathrm{ab}}$ & $1620.33 \pm 211.200^{\mathrm{abc}}$ & $73.67 \pm 27.30^{\mathrm{b}}$ & $477.00 \pm 28.93$ & $808.00 \pm 169.46^{b}$ & $1111.67 \pm 162.52^{\mathrm{ab}}$ \\
\hline
\end{tabular}

The different letter of superscripts indicated the significant difference $(\mathrm{p}<0.05)$ 
reproductive traits, chickens with $\mathrm{AA} / \mathrm{CD} / \mathrm{EE}$ had first egg significantly earlier than those with $\mathrm{AA} / \mathrm{CC} / \mathrm{EE}$ and $\mathrm{AB} / \mathrm{CC} / \mathrm{EF} \quad(\mathrm{p}<0.05)$. Chickens with $\mathrm{AA} / \mathrm{CC} / \mathrm{EF}$ and $\mathrm{AA} / \mathrm{DD} / \mathrm{EE}$ had higher beginning-laying-weight than those with $\mathrm{AA} / \mathrm{CD} / \mathrm{EF}$ and chickens with $\mathrm{AA} / \mathrm{CC} / \mathrm{EF}$ had higher beginning-laying-weight than those with $\mathrm{BB} / \mathrm{CC} / \mathrm{FF}$. Chickens with $\mathrm{AB} / \mathrm{CC} / \mathrm{EE}$ had higher 300 days egg number than those with $\mathrm{BB} / \mathrm{CD} / \mathrm{EE}$. For body weight, the differences between all com-genotypes were not significant at hatch day 4 and 8 weeks $(\mathrm{p}>0.05)$. Chickens with $\mathrm{AA} / \mathrm{DD} / \mathrm{EE}$ had the highest body weight at 12 weeks, significantly higher than those with $\mathrm{AA} / \mathrm{CC} / \mathrm{EE}$, $\mathrm{AA} / \mathrm{CD} / \mathrm{EE}, \quad \mathrm{AA} / \mathrm{CD} / \mathrm{EF}, \quad \mathrm{AB} / \mathrm{CC} / \mathrm{EE}, \quad \mathrm{AB} / \mathrm{CC} / \mathrm{EF}$, $\mathrm{AB} / \mathrm{CD} / \mathrm{EE}$ and $\mathrm{BB} / \mathrm{CD} / \mathrm{EE}$. Chickens with $\mathrm{AA} / \mathrm{CC} / \mathrm{EF}$ had higher body weight at 16 weeks than those with $\mathrm{AA} / \mathrm{CC} / \mathrm{EE}, \mathrm{AB} / \mathrm{CC} / \mathrm{EF}, \mathrm{BB} / \mathrm{CC} / \mathrm{FF}$.

\section{DISCUSSION}

PCR-SSCP was an ease and economic experimental technique for detecting SNPs combined with the direct sequencing of DNA pooling, it made the screening even faster and more correct. In this study, researchers found three SNPs in exon 2 of IGF-IR gene through this method. The screening result showed there was mere $3 \mathrm{bp}$ interval between two mutation loci (26333 and 26336 bp) which would bring some difficulties to further detect if only through PCR-SSCP. So, when designed primer P1, researchers made the base of $26336 \mathrm{bp}$ in the primer P1 then the SNP at 26333 bp was detected by SSCP easily. The base mutation at 26336 bp was detected by RFLP making use of the loss of Alu I endonuclease site. At last, three SNPs were all checked out successfully, fully avoiding omission and erroneous judgment because of the direct sequencing of DNA pooling. Population analysis showed the three SNPs were all in Hardy-Weinberg equilibrium which meant the three SNPs were not affected by breeding selection or re-achieved equilibrium state through eight generations breeding.

$I G F-I R$ gene is the member of the transmembrane tyrosine kinase receptor family plays a mitogen role in promoting cell proliferation (Coppola et al., 1994). In IGF-IR gene deficient mouse fibroblast, EFG and PDGF did not stimulate DNA synthesis and cell proliferation, but these defects could be corrected by high expression of IGF-IR gene (Coppola et al., 1994; DeAngelis et al., 1995). Mice lacking functional IGF-1Rs were born weighing less than half the normal weight and die soonthere after (Liu et al., 1993).

As the only receptor of IGF-I and IGF-II in birds, IGF-IR plays an important role for IGFs' biological functions and $I G F-I R$ gene was studied as an important candidate gene with growth and development for poultry (Armstrong and Hogg, 1992; Gao et al., 2009). In this study, G to A transition at 26333 bp had significant effect on reproductive traits in Jinghai yellow chicken. Chickens with $\mathrm{BB}$ genotype had less 300 days egg number than those with $\mathrm{AA}$ and $\mathrm{AB}$ (short of 18.54 and 19.36, respectively) which showed $A$ was a reproductive enhancer gene and $\mathrm{B}$ was a leaky one. Body weight of chickens with $\mathrm{BB}$ was 24.70 and $18.36 \mathrm{~g}$ less than that of $\mathrm{AA}$ and $\mathrm{AB}$, respectively at 4 week and it also significantly less than those with $\mathrm{AA}(<82.12 \mathrm{~g})$ at 16 week which verified that B was a leaky gene for body weight. For primer P2, body weight of chickens with DD was 47.61 and $106.22 \mathrm{~g}$ higher than those with $\mathrm{CC}$ which meant the $\mathrm{G}$ to $\mathrm{A}$ transition at $26336 \mathrm{bp}$ was positively associated with body weight at 8 and 12 weeks. Analysis of primer P3 showed $\mathrm{F}$ was a leaky gene for body weight at 16 week.

Com-genotypes analysis showed that the age at the first egg of chickens with $\mathrm{AA} / \mathrm{CD} / \mathrm{EE}$ was the earliest, 5 and 6 days earlier than those with $\mathrm{AA} / \mathrm{CC} / \mathrm{EE}$ and $\mathrm{AB} / \mathrm{CC} / \mathrm{EF}$, respectively which meant $\mathrm{AA} / \mathrm{CD} / \mathrm{EE}$ could be an advantage com-genotype for improving the age at first egg. Chickens with $\mathrm{AA} / \mathrm{CC} / \mathrm{EE}$ had 30 eggs more than those with $\mathrm{BB} / \mathrm{CC} / \mathrm{EE}$ at 300 days which indicated that the $\mathrm{AA} / \mathrm{CC} / \mathrm{EE}$ was beneficial to the improvement of 300 days egg number in Jinghai Yellow chicken. Chickens with $\mathrm{AA} / \mathrm{CC} / \mathrm{EF}$ had more 98.509-183.000 g body weight than any other at 12 weeks which meant $\mathrm{AA} / \mathrm{CC} / \mathrm{EF}$ could be the most advantageous com-genotype for body weight at this age. Meanwhile $\mathrm{AA} / \mathrm{CC} / \mathrm{EF}$ was a favorable com-genotype for body weight at 16 weeks. Chickens with $\mathrm{AA} / \mathrm{CC} / \mathrm{EE}$ and $\mathrm{AB} / \mathrm{CC} / \mathrm{EF}$ had low body weight at 12 and 16 weeks.

\section{CONCLUSION}

Jinghai Yellow chicken was a high quality, small meat chicken breed, its growth curve turning point was about 11.13 week (Yang et al., 2007) and the selling time of its breeding objective was about 16 weeks age. Researchers detected three SNPs in exon 2 of IGF-IR gene in female Jinghai yellow chicken and the result showed these mutations had some effects on production performances especially on the body weight at 12 and 16 week, the time for its selling. Further study involving larger sample size and male chickens will be needed to confirm the association between these SNPs and production performances in Jinghai yellow chicken and/or in other chicken breeds. 


\section{ACKNOWLEDGEMENTS}

This research was founded by National Broiler Industrial and Technology System (No.nycytx-42-G1-05). The researchers gratefully acknowledge the members of Jinghai Poultry Group Corporation in Jiangsu Province for providing experimental animals.

\section{REFERENCES}

Armstrong, D.G. and C.O. Hogg, 1992. The expression of a putative insulin-like growth factor-I receptor gene in the liver of the developing chick. Mol. Endocrinol., 8: 193-201.

Baserga, R., C. Sell, P. Porcu and M. Rubini, 1994. The role of the IGF-I receptor in the growth and transformation of mammalian cells. Cell Prolif., 27: 63-71.

Bhaumick, B., R.M. Bala and M.D. Hollenberg, 1981. Somatomedin receptor of human placenta: solubilization, photolabeling, partial purification and comparison with insulin receptor. Proc. Natl. Acad Sci., 78: 4279-4283.

Burfeind, P., C.L. Chernicky and F. Rininsland, 1996. Antisense RNA to the type 1 insulin-like growth and prevents invasion by rat prostate cancer cells in vivo. Proc. Natl. Acad Sci. USA, 93: 7263-7268.

Chernausek, S.D., S, Jacobs and J.J. Van Wyk, 1981. Structural similarities between human receptors for somatomedin $\mathrm{C}$ and insulin: Analysis by affinity labeling. Biochemistry, 20: 7345-7350.

Coppola, D., A. Ferber, M. Miura, C. Sell, C. D'Ambrosio, R. Rubin and R. Baserga, 1994. A functional insulinlike growth factor I receptor is required for the mitogenic and transforming activities of the epidermal growth factor receptor. Mol. Cell. Biol., 14: 4588-4595.

DeAngelis, T., A. Ferber and R. Baserga, 1995. Insulin-like growth factor 1 receptor is required for the mitogenic and transforming activities of platelet derived growth factor receptor J. Cell. Physiol., 164: 214-221.

Denley, A., L.J. Cosgrove, G.W. Booker, J.C. Wallace and B.E. Forbes, 2005. Molecular interactions of the IGF system. Cytokine Growth Factor Rev., 16: 421-439.

Donovan, E.A. and S. Kummar, 2008. Role of insulin-like growth factor-1R system in colorectal carcinogenesis. Crit. Rev. Oncol. Hematol., 66: 91-98.

Gao, F.H., L.H. Bian, S.Z. Wang, Q.G. Wang, Z.Q. Tang and H. Li, 2009. Association of chicken IGF1R gene with growth and body composition traits. J. Northeast Agri. Univ., 40: 77-83.
Lei, M.M., Y.B. Tang, M. Zhou, X.B. Shao, X. Peng and $\mathrm{X}$.Q. Zhang, 2006. Analysis on genetic diversities of $I G F 1 R$ gene in chicken. Guangdong Agric. Sci., 11: $132-137$.

Leroith, D., H. Werner, D. Beitner-Johnson and A.T. Jr. Roberts, 1995. Molecular and cellular aspects of the insulin-like growth factor I receptor. Endocr. Rev., 16: 143-163.

Liu, J.P., J. Baker, A.S. Perkins, E.J. Robertson and A. Efstratiadis, 1993. Mice carrying null mutations of the genes encoding insulinlike growth factor I (Igf-1) and type $1 \mathrm{IGF}$ receptor (Igfr). Cell, 75: 59-72.

Massague, J. and M.P. Czech, 1982. The subunit structures of two distinct receptors for insulin-like growth factors I and II and their relationship to the insulin receptor. J. Biol. Chem., 257: 5038-5045.

Matsumura, Y., M. Domeki, K. Sugahara, T. Kubo, C.T. Jr. Roberts, D. LeRoith and H. Kato, 1996. Nutritional regulation of insulin-like growth factor-I receptor mRNA levels in growing chickens. Biosci. Biotechnol. Biochem., 60: 979-982.

Meyts, P.D., B. Wallach, C.T. Christoffersen, B. Urso and K. Gronskov et al., 1994. The insulin-like growth factor-I receptor structure, ligand-binding mechanism and signal transduction. Horm. Res., 42: 152-169.

Moe, H.H., T. Shimogiri, W. Kamihiraguma, H. Isobe and $\mathrm{K}$. Kawabe et al., 2007. Analysis of polymorphisms in the insulin-like growth factor 1 receptor (IGF1R) gene from Japanese quail selected for body weight. Anim. Genet., 38: 659-661.

Rappolee, D.A., K.S. Sturm, O. Behrendtsen, G.A. Schultz, R.A. Pedersen and Z. Werb, 1992. Insulin-like growth factor II acts through an endogenous growth pathway regulated by imprinting in early mouse embryos. Genes Dev., 6: 939-952.

Serrat, M.A., C.O. Lovejoy and D. King, 2007. Age- and site-specific decline in insulin-like growth factor-I receptor expression is correlated with differential growth plate activity in the mouse hindlimb. Anat. Record, 290: 375-381.

Waksmanski, B., J. Dudkiewicz and S. Dabrowski, 2001. Function of insulin-like growth factor (IGF-I) and its binding protein (IGFBP-1) in pathological proliferation of endometrium. Wiadomosci lekarskie, 54: 656-661.

Wang, Y., S. Nishida, B.M. Boudignon, A. Burghardt, H.Z. Elalieh et al., 2007. IGF-I Receptor is required for the anabolic actions of parathyroid hormone on bone. J. Bone Miner. Res., 22: 1329-1337. 
Wargelius, A., P.G. Fjelldal, S. Benedet, T. Hansen, B.T. Bjornsson and U. Nordgarden, 2005. A peak in gh-receptor expression is associated with growth activation in Atlantic salmon vertebrae, while upregulation of igf-I receptor expression is related to increased bone density. Gen. Comp. Endocrinol., 142: 163-168.

Xu, S., Y. Tao, Z. Yang and J. Chu, 2002. A simple and rapid methods used for silver staining and gel preservation. Hereditas, 24: 335-336.
Yang, Y., J.Y. Wang, L.Y. Wang, J.H. Yu and S.J. Lu, 2007. Analysis of fitting growth model in Jinghai yellow chicken. Anim. Husb. Vet. Med., 39: 17-20.

Zhao, H., J. Dupont, S. Yakar, M. Karas and D. LeRoith, 2004. PTEN inhibits cell proliferation and induces apoptosis by downregulating cell surface IGF-IR expression in prostate cancer cells. Oncogene, 23: 786-794. 